\title{
FORMULATION AND ANTIBACTERIAL ACTIVITY TEST OF Staphylococcus aureus MICROEMULSION OF ANTING-ANTING (Acalypha indica) LEAF EXTRACT USING ISOPROPYL MIRISTAT AS OIL PHASE
}

\author{
${ }^{1}$ Jauharatul Husniyah, ${ }^{2} *$ Rahmi Annisa, and ${ }^{2}$ Burhan Ma'arif \\ ${ }^{1}$ Student of Department of Pharmacy, Faculty of Medical and Health Sciences, Maulana Malik Ibrahim State \\ Islamic University \\ Jl. Gajayana No. 50 Malang 65144 \\ ${ }^{2}$ Department of Pharmacy, Faculty of Medical and Health Sciences, Maulana Malik Ibrahim State Islamic \\ University \\ Jl. Gajayana No. 50 Malang 65144

\begin{abstract}
*Corresponding author, email: apt.rahmiannisa@gmail.com Co-author, email: burhan.maarif@farmasi.uin-malang.ac.id
\end{abstract} \\ Co-author, email: jauhar.husnia@gmail.com
}

\begin{abstract}
Leaf of Anting-Anting (Acalypha indica) is one of the plants that contain potent flavonoid compounds as antibacterial Staphylococcus aureus. The purpose of this research is to know physical characteristic of microemulsion of A. Indica leaf extract and to know antibacterial activity against Staphylococcus aureus bacteria. The microemulsions in this study used isopropyl myristate as the oil phase, tween 80 and span 80 as surfactant, isopropanol as kosurfactant and free water from $\mathrm{CO}_{2}$. Microemulsion was made by varying the concentration of the extract into 3 formulas, there are 5\%,10\% and 15\%. A. indica extract obtained using ultrasonic maseration extraction method with $70 \%$ ethanol solvent. All the formulas were evaluated for the characteristics of the preparations and the antibacterial activity test against Staphylococcus aureus bacteria with the sumuran diffusion method. The research results showed that the microemulsion of A. indica leaf extract has good physical characteristic with $\mathrm{pH}$ value between 4.9-5.8, deep oil type, that particle size F1 $9.34 \mu \mathrm{m}, \mathrm{F} 2$ $14.22 \mu \mathrm{m}$ and $\mathrm{F3} 9.68 \mu \mathrm{m}$ and stable physically at $25^{\circ} \pm 2^{\circ} \mathrm{C}$ and $40^{\circ} \pm 2{ }^{\circ} \mathrm{C}$. The result of antibacterial activity test showed that F1 did not differ significantly with positive control. However, the inhibitory power of F1 is still under positive clindamycin control of $12.98 \mathrm{~mm}$ and $15.05 \mathrm{~mm}$. So it can be collected that F1 is an ideal formula which has good physical characteristics and has optimum drag power.
\end{abstract}

Keywords: Antibacterial, Microemulsion, Anting-anting (Acalypha indica) Leaf Extract, Staphylococcuss aureus.

\section{INTODUCTION}

Acne is a skin disease characterized by an inflammatory reaction in the follicle polisebasea in areas containing many sebaceous glands such as face, neck, upper arm, chest and back [1]. The occurrence of acne can be due to increased sebum production. Increased production of sebum in acne sufferers are affected by androgen hormones. Accumulation of sebum can be a source of nutrients for acne-causing bacteria such as Propionibacterium acne, 
Staphylococcus epidermidis and Staphylococcus aureus resulting in inflammation and acne formation [2].

Therapy given when the emergence of acne is the provision of antibiotics and nonantibiotic acne medicine. However, the use of antibiotics that are not rational and excessive can encourage resistance to certain bacteria. While treatment with non-antibiotic acne medications available today in topical dosage forms, it has a high efficacy but potentially cause side effects. Common side effects that can cause irritant contact dermatitis on the skin for example in retinoids. In addition, the use of non-antibiotic acne medications such as isotretinoin may be teratogenic in pregnant women. Therefore, it is necessary to find other alternatives by utilizing natural materials are considered more secure and have a good effectiveness for health. Plants that have the potential as an alternative material for drug therapy due to bacterial infection are $A$. indica.

A. indica plants have secondary metabolite compounds that have antibacterial effects of flavonoids. Based on the results of phytochemical screening performed on A. indica plants showed that the plant extract contained flavonoids, saponins and tannins [3]. It is known that A. indica plants contain flavonoid and tannin compounds. In this solvent plant extract variation, flavonoid compounds can be used as antimicrobials that have inhibitory activity against gram-positive bacteria such as $S$. aureus and S. epidermidis and gram-negative bacteria such as Klebsiella pneumoniae and E.coli [4].

In an effort to improve the use of these herbs it is necessary to be made in a dosage form which can deliver the drug well and not aggravate the acne condition. One such preparation is microemulsions. microemulsions may increase the solubility of hydrophilic and lipophilic active compounds. In addition, this preparation has a very small particle size of 0.1-10 $\mu \mathrm{m}$ so it can penetrate well in the skin and can increase the antibacterial effectiveness of $A$. indica extract. The purpose of this research is to know physical characteristic of microemulsion preparation of $A$. indica leaf extract and to know formula with optimum concentration in inhibiting the growth of $S$. aureus bacteria.

\section{MATERIAL AND METHOD}

\section{Materials}

The materials used in this research are leaf of simplicia leaf A. indica from Balai Materia Medika Batu, Staphylococcus aureus bacteria, ethanol solvent 70\% pharmaceutical grade (PT Bratachem), Nutrient Agar (NA) media, isopropyl myristist pa (PT Bratachem), tween 80 pa 
(PT Bratachem), span 80 pa (PT Bratachem), Isopropanol pa (PT Bratachem), aquades and clindamycin phosphate 1.2\%, acetic acid, butanol, sulfuric acid, silica gel 60 F254 (Merck KgaA), Mg metal powders, $\mathrm{HCl}$, methanol, DMSO and methylen blue.

\section{Research Methods}

The type of microemulsion made in this research is the type of microemulsion oil in water $(\mathrm{o} / \mathrm{w})$. The microemulsion formulation of ethanol extract of $A$. indica leaf is shown in Table 1. The water phase includes tween $80, \mathrm{CO}_{2}$ free water and $A$. indica leaf extract. While the oil phase includes isopropyl myristist, span 80 and isopropanol. Furthermore, the oil phase is mixed and stirred using a magnetic stirer speed of $\pm 1400 \mathrm{rpm}$ for 15 minutes. As for the phase of stirred oil using a magnetic stirer speed $\pm 1400 \mathrm{rpm}$ for 15 minutes with a temperature of $40^{\circ} \mathrm{C}$. Then the oil phase and water phase are mixed together and stirred using a magnetic stirer at a rate of $\pm 1400 \mathrm{rpm}$ for 15 minutes.

\section{Evaluation of Microemulsion}

\section{Organoleptic Test}

Microemulsion preparations are observed visually ie shape, color, and odor.

\section{pH Test}

a total of 1 gram of microemulsion preparation measured $\mathrm{pH}$ value by using $\mathrm{pH}$ meter. Then the $\mathrm{pH}$ value of microemulsion was adjusted to skin $\mathrm{pH}$, that is 4.5-6,5 [5].

\section{Stability Test Cycling test}

Samples are stored at $4{ }^{\circ} \mathrm{C}$ for 48 hours then transferred into a $40 \pm 2^{\circ} \mathrm{C}$ oven for 48 hours, the storage time of the two temperatures is considered one cycle. Stability test carried out over 3 cycles then observed the presence or absence of phase separation and inversion [6].

\section{Type of Microemulsion}

a microemulsion type examination is performed by sprinkling a water-soluble dye, ie methylene blue on the surface of the preparation on top of the object glass and observed under an optical microscope.

\section{Pacticle Size Test}

Measurements were made using Particle Size Analyzer (PSA) series zatasizer (Malvern). The expected particle size is included in the range between 0.1-10 $\mu \mathrm{m}$ [7].

\section{Antibacterial Activity Test}

The antibacterial test method used in this study is the diffusion of wells. Suspension of Staphylococcus aureus bacteria is mixed with Nutrient media to be sterile, then sterilized to half hardened. Furthermore, wells are made by using a cork drill on a medium plate with a 
diameter of $\pm 8 \mathrm{~mm}$. One petri dish contains three wells with a set distance of the wells that have been arranged so that the observation area does not coexist. Thereafter, microemulsion preparations of $A$. indica leaf extract (5\%,10\% and 15\%), microemulsions without extract (negative control), clindamycin phosphate 1,2\% (positive control) and sterile water (comparison) in each well which has been marked. Then put the plate into the incubator and wait for 24 hours at $37^{\circ} \mathrm{C}$. There will be a clear area around a clean well or no bacterial colony, called a drag zone. Calculated drag zone diameter.

\section{RESULTS AND DISCUSSION}

\section{Organoleptic test}

Organoleptic observation, there are three clear and transparent microemulsions, blackish brown, liquid, distinctive, and homogeneous.

\section{pH test}

The $\mathrm{pH}$ value generated from the three formulas is between 4.9-5.63. At the $\mathrm{pH}$ value, it meets the tolerable $\mathrm{pH}$ range for no skin irritation that is 4.5-6.5 [5].

\section{Stability of Cycling test}

The parameters of microemulsion stability in this study were based on organoleptic parameters and $\mathrm{pH}$ values which were preelled before and after storage. The result of organoleptic observation after Cycling test is microemulsion in the form of clear and transparent liquid, blackish brown, distinctive smell, and homogenous. This result is similar to organoleptic test results before storage. This indicates that the three microemulsion formulas of $A$. indica leaf extract are stable based on organoleptic parameters.

The result of $\mathrm{pH}$ observation before and after Cycling test on three microemulsion formulas of $A$. indica leaf extract is shown in table 2.

Based on these results, it is known that in F1, F2, and F3 obtained p-value> 0,05 indicating that there is no significant difference between $\mathrm{pH}$ value before and after done cycling test. So it can be concluded that microemulsion preparation of $A$. indica leaf extract is stable based on parameter of $\mathrm{pH}$ value.

\section{Type of Microemulsion}

The result of observation of microemulsion type on all formulation formula is oil in water $(\mathrm{m} / \mathrm{a})$. This is evidenced by the blue dispersed medium, while the dopplet dispersion phase is not blue. Methylen blue is a water-soluble color, which causes the medium dispers of a 
water-ultimately blue-watered microemulsion system, while the dispersion droplet is not blue.

\section{Particle Size Test}

The expected particle size is included in the range between 0.1-10 $\mu \mathrm{m}$ [7]. The result of microemulsion particle measurement of $A$. indica leaf extract can be seen in table 4 .

\section{Antibacterial Activity}

The result of antibacterial activity test is shown by the inhibition zone of clear area around the well containing microemulsion of A. indica extract. The provision of antibacterial power, which is a $20 \mathrm{~mm}$ or more obstacle area, is a very strong category, a strong category 10-20 $\mathrm{mm}$ obstacle area, a 5-10 $\mathrm{mm}$ medium area and a $5 \mathrm{~mm}$ or more resistance area including a weak category [8]. The results of microbial activity antibacterial activity of $A$. indica extract can be seen in table 5 and figure 1.

F1, F2 and F3 differ significantly with F4 which is microemulsions without extracts. While F4 did not differ significantly with negative control. This proves that the antibacterial effect of the three formulas (F1, F2 and F3) is derived from leaf extract of $A$. indica. $\mathrm{F} 2$ and F3 differ significantly with positive controls. While F1 did not differ significantly with positive control. This indicates that $\mathrm{F} 1$ has the same antibacterial activity as positive control of $S$. aureus bacteria.

In this test it appears that the microemulsion of $A$. indica extracts with higher concentrations of $10 \%$ and $15 \%$ did not provide a larger inhibition zone than the 5\% concentration. This shows that the higher extract concentration does not increase the diameter of the inhibited zone. Decreased inhibitory zone diameter is suspected to be influenced by higher concentrations of extract causing more concentrated extracts so that diffuse extract diffuses into bacterial-containing media. The diameter of the inhibitory zone is not always directly proportional to the increase in concentration, this possibility occurs due to differences in the diffusion speed of antibacterial compounds on the agar medium [9]. Other influential factors such as interaction between medium components and environmental conditions [10].

\section{CONCLUSION}

Based on the research that has been done then it can be concluded that microculsion of leaf extract $A$. indica has a yellowish color to blackish brown, has a distinctive odor of extract with a slightly viscous liquid consistency, has a $\mathrm{pH}$ between 4.9 to 5.63 , is physically stable, 
has an oil type in water, and has a particle size between 9,34-14,22. F1 microemulsion with concentration of $5 \%$ extract is the optimum concentration in inhibiting the growth of $S$. aureus bacteria and not significantly different with positive control that is clindamycin phosphate.

\section{REFERENCES}

[1] Wasiaatmadja, S.M. 1997. Penuntun Ilmu Kosmetik Medik. UI Press. Jakarta.

[2] Mitsui, T. 1997. New Cosmetic Science. Edisi Kesatu. Amsterdam: Elsevier Science B.V.Hal. 13,19-21

[3] Vijayarekha P. Sangottaiyan N, Noorjahan A. and Ambiga S. (2015). "Antibacterial Activity of Acalypha indica Linn". International Journal of Current Microbiology and Applied Sciences. 4 (6): 1133-1138.

[4] Cholapandian K, Jesubell R. B. Arunkumar R, Boopalan K. (2013). “Antibacterial Activity of Acalypha Indica Extracted with Various Solvents". International Journal of Ethnomedicine and Pharmacological Research. Vol.1 Issue 1, P.1-6.

[5] Tranggono, Retno Iswari dan Fatma Latifah. 2007. Buku Pegangan Ilmu Kosmetik. Jakarta : PT Gramedia Pustaka Utama.

[6] Djajadisastra, J. Abdul M., Dessy NP. Formulasi Gel Topikal Dari Ekstrak Nerii Folium Dalam Sediaan Anti Jerawat. Jakarta. Jurnal Farmasi Indonesia. 2009. Vol. 4. Hal:210-216.

[7] Nikumbh, K. V., Sevankar, S. G., and Patil, M. P. 2013. Formulation Development In Vitro and In Vivo Evaluation of Microemulsion-based Gel Loaded With Ketoprofen. Informa Healthcare USA.

[8] Davis, W.W and Stout, T. R. 1971. Disc Plate Methods of Microbiological Antibiotic Assay. Microbiology. 22(4): 659-665.

[9] Dewi, F. K. 2010. Aktivitas Antibakteri Ekstrak Etanol Buah Mengkudu (Morinda citrifolia L.) terhadap Bakteri Pembusuk Daging Segar [Skripsi], Jurusan Biologi FMIPA. Universitas Sebelas Maret. Surakarta.

[10] Mickel, A. K., P. Sharma., S, Chogle. 2003. Effectiveness of Stannous Fluoride and Calcium Hydroxide against Enterococcus faecalis. J. Endod 29 (4):259-60.

Table 1. Formulation of microemulsion system of $A$. indica leaf extract

\begin{tabular}{lccccc}
\hline \multirow{2}{*}{ Ingredient } & Function & \multicolumn{3}{c}{ Formula Concentration (w / v) } \\
\cline { 3 - 6 } & & F1 & F2 & F3 & F4 \\
\hline Leaf $A$. indica extract & Active substance & $5 \%$ & $10 \%$ & $15 \%$ & - \\
Isopropyl myristate & Oil phase & $10 \%$ & $10 \%$ & $10 \%$ & $10 \%$ \\
Tween 80 & Surfactant & $32 \%$ & $32 \%$ & $32 \%$ & $32 \%$ \\
Span 80 & Surfactant & $2,5 \%$ & $2,5 \%$ & $2,5 \%$ & $2,5 \%$ \\
Isopropanol & Co-surfaktan & $12,5 \%$ & $12,5 \%$ & $12,5 \%$ & $12,5 \%$ \\
Aquadest $(\mathrm{mL})$ add & Solvent & $100 \%$ & $100 \%$ & $100 \%$ & $100 \%$ \\
\hline
\end{tabular}


Table 2. Results of Microemulsion pH Test Before and After Cycling Test

\begin{tabular}{ccc}
\hline Formula & $\begin{array}{c}\mathbf{p H} \text { test before } \\
\text { test } \text { Cycling test }\end{array}$ & $\begin{array}{c}\mathbf{p H} \text { test after } \\
\text { Cycling test }\end{array}$ \\
\hline F1 & $5,63 \pm 0,15275$, & $5,5 \pm 0,1$ \\
F2 & $5,5 \pm 0,2645$ & $5,46 \pm 0,1527$ \\
F3 & $5,1 \pm 0,1$ & $4,9 \pm 0,1$ \\
\hline
\end{tabular}

Table 3. Results of microemulsion particle size of $A$. indica extract

\begin{tabular}{cc}
\hline Formula & Ukuran Partikel $(\boldsymbol{\mu m}) \pm$ SD \\
\hline F1 & $9,34 \cdot 10^{-3} \pm 0,0204$ \\
F2 & $14,22.10^{-3} \pm 0,1833$ \\
F3 & $9,68.10^{-3} \pm 0,1516$ \\
\hline
\end{tabular}

Table 4. Results of antibacterial activity test

\begin{tabular}{lcc}
\hline \multicolumn{1}{c}{ Formula } & $\begin{array}{c}\text { Average diameter resistance area } \\
(\mathbf{m m}) \pm \text { SD }\end{array}$ & Category \\
\hline F1 & $12,98 \pm 1,628$ & Strong \\
F2 & $8,75 \pm 0,957$ & Medium \\
F3 & $8,33 \pm 1,068$ & Medium \\
F4 & $3,55 \pm 0,433$ & Poor \\
Klindamisin (positive control) & $15,05 \pm 1,105$ & Strong \\
Steril water (negative control) & $0 \pm 0$ & - \\
\hline
\end{tabular}

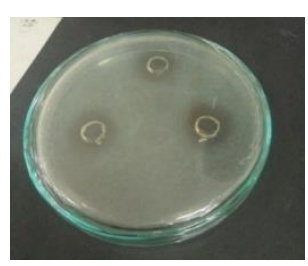

A

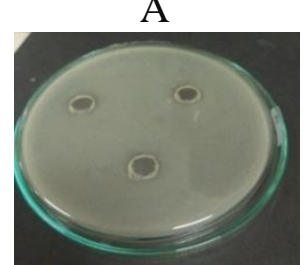

$\mathrm{D}$

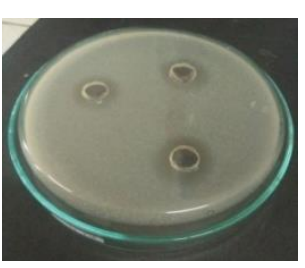

B

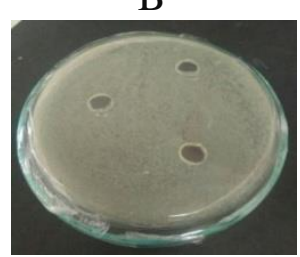

$\mathrm{E}$

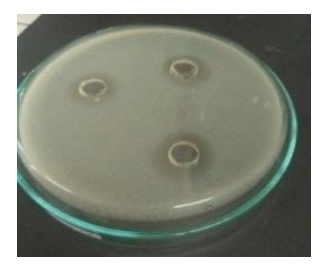

C

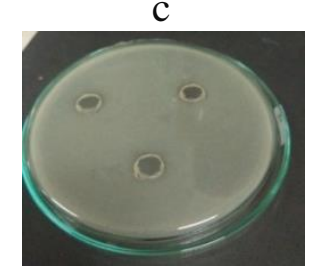

f

Figure 1. Results of antibacterial test; a. F1 with extract concentration 5\%; b. F2 with extract concentration of $10 \%$; c. F3 with extract concentration 15\%; d. F4 with concentration of extract $0 \%$; e. $\mathrm{K}(-)$ in the form of sterile water; $\mathrm{f} . \mathrm{K}(+)$ in the form of tetracycline antibiotics 